\title{
HABITUATION TO SIGNING CHILDREN'S SONGS TO EMBED CHARACTER VALUE! LOW GRADE STUDENTS OF SDN 1 DEPOKREJO
}

\author{
Heni Rahmawati, Anjar Wijiatmiko, Novia Indrianingsih, Rokhmaniah \\ Universitas Sebelas Maret \\ henirahmawati@student.uns.ac.id
}

\section{Article History}

accepted 30/09/2018

approved 12/10/2018

published $30 / 10 / 2018$

\begin{tabular}{ll} 
Keywords & \\
\hline character & value, \\
children's song &
\end{tabular}

\begin{abstract}
Children's songs contain many character values. So that the character values contained in these songs can be measured in the souls of children, it is necessary to spread the habit of singing children's songs. Research activities need to be carried out in order to find out ways and activities of habituation to sing children's songs in instilling character values. The approach taken in this study is qualitative research with low-grade students at Depokrejo 1 Elementary School. Primary data sources are obtained by interviewing teachers and direct observation. To maintain the validity of the data, this study uses a triangulation method. The results showed that the habit of singing children's songs to low-grade students at Depokrejo 1 Elementary School was successful and could make students better than before, for example more fellow friends, forgiveness, courtesy, maintaining cleanliness, and so on.
\end{abstract}

Social, Humanities, and Education Studies (SHEs): Conference Series https://jurnal.uns.ac.id/shes
p-ISSN 2620-9284

e-ISSN 2620-9292 


\section{PENDAHULUAN}

Undang - Undang No 20 Tahun 2003 tentang Sistem Pendidikan Nasional menyebutkan tujuan pendidikan nasional yang tercantum dalam pasal 3 adalah "Pendidikan nasional berfungsi mengembangkan kemampuan dan membentuk watak serta peradaban bangsa yang bermartabat dalam rangka mencerdaskan kehidupan bangsa, bertujuan untuk berkembangnya potensi peserta didik agar menjadi manusia yang beriman dan bertakwa kepada Tuhan Yang Maha Esa, berakhlak mulia, sehat, berilmu, cakap, kreatif, mandiri, dan menjadi warga negara yang demokratis serta bertanggung jawab." Hal tersebut sangat jelas menunjukan bahwa tujuan utama pendidikan nasional tidak lain adalah untuk membentuk karakter yang baik. Untuk merealisasikan tujuan pendidikan nasional tersebut, tentu seluruh lembaga pendidikan perlu adanya upaya-upaya kreatif dan efektif sesuai dengan sasarannya.

Sudirman dalam Indrastoeti (2016) mengemukakan bahwa karakter merupakan nilai-nilai perilaku manusia yang berhubungan dengan Tuhan Yang Maha Esa, diri sendiri, sesama manusia, lingkungan dan kebangsaan yang terwujud dalam pikiran, sikap perasaan, perkataan, dan perbuatan, berdasarkan norma-norma agama, hukum, tata krama, budaya dan adat istiadat.

Character is the foundation of self development, Character formation requires the development of traits such as purity, perseverance, faith, sincerity, obedience, fortitude, veneration, humanistic tendency, etc (Shrivastava, 2017). Character education is essential for building a moral society, and it is the conscious effort to cultivate virtue. The psychological components of character education encompass the cognitive, affective, and behavioral aspects of morality such as, moral knowing, moral feeling, and action (Lickona in Chowdhury, 2016)

Sehingga dapat dikatakan bahwa karakter adalah sifat, perilaku, budi pekerti yang baik yang dimiliki oleh manusia. Karakter seseorang sangat dipengaruhi oleh faktor dari luar seperti perkembangan lingkungan dan pergaulan. Karakter tersebut dapat dipupuk dan dikembangkan menjadi semakin baik. Namun, juga dapat mengalami penurunan apabila terpengaruh oleh hal-hal yang bersifat negatif.

Seiring berkembangnya zaman dan era globalisasi, perubahan dalam aspek kehidupan terus terjadi. Arus globalisasi tersebut tentu memberikan dampak positif dan negatif yang tidak bisa dihindari. Salah satu dampak dari globalisasi yaitu dapat kita lihat dalam dunia permusikan. Saat ini banyak sekali bermunculan berbagai jenis lagu dari berbagai aliran atau genre musik seperti dangdut, rock, pop, jaz, dan bahkan banyak lagi lagu dari negara lain yang juga marak di masyarakat. Lagu tersebut bukanlah lagu yang seharusnya dikonsumsi oleh anak-anak karena isi yang terkandung didalamnya lebih bersifat dewasa dan tidak sesuai dengan perkembangan anak. Seharusnya, anak lebih diarahkan untuk mengenal dan mengerti isi dari lagu anak-anak karena di dalamnya terdapat nilai-nilai yang bersifat mendidik. Lagu anak adalah lagu yang dirancang dan disesuaikan dengan karakteristik anak. Lagu anak memiliki sifat yang ceria dan bahasanya bersifat sederhana. Lagu anak dibuat untuk mengungkapkan kegembiraan, kasing sayang, dan memiliki nilai pendidikan yang sesuai dengan tingkat psikologis anak. Syair lagu anak biasanya bercerita tentang cinta kasih pada sesama, Tuhan, ayah-ibu, kakak-adik, keindahan alam, kebesaran Tuhan yng ditulis dengan bahasa sederhana sesuai dengan alam pikir anak-anak (Kusumawati, 2013 :05).

Banyaknya nilai-nilai karakter yang terkandung dalam lagu anak-anak menjadi alasan bagi SDN 1 Depokrejo dalam usaha menanamkan pendidikan karakter melalui kegiatan pembiasaan menyanyikan lagu anak-anak. Berkaitan dengan hal tersebut yang perlu kita ketahui adalah bagaimana cara yang harus dilakukan oleh guru agar nilai-nilai yang terkandung dalam sebuah lagu anak dapat tersampaikan dengan baik dan dapat dilaksanakan oleh siswa. Selain itu, tingkat keefektifan dari usaha ini juga perlu diketahui. Oleh karena itu, maka dilakukanlah penelitian dengan metode kualitatif 
deskriptif dalam rangka untuk mengetahui bagaimanakah cara yang dilakukan guru SDN 1 Depokrejo khususnya pada kelas rendah untuk menanamkan nilai-nilai karakter bagi siswa menggunakan lagu anak, serta untuk mengetahui apakah penanaman nilainilai karakter melalui kegiatan pembiasaan menyanyikan lagu anak-anak dapat dikatakan efektif atau tidak.

\section{METODE}

Metode yang digunakan dalam penelitian ini adalah metode penelitian yang bersifat kualitatif deskriptif. Penelitian kualitatif deskriptif menurut Sudarwan dalam Nafis (2013) maksudnya yaitu data yang dikumpulkan berbentuk kata-kata, gambar, bukan angka-angka. Atau dapat dikatakan bahwa penelitian deskriptif merupakan prosedur penelitian yang menghasilkan data deskriptif berupa kata-kata tertulis, lisan atau perilaku informan yang diamati.

Data hasil penelitian diperoleh dengan cara wawancara dan diolah hingga memperoleh keterangan yang berguna kemudian di analisis. Untuk menjaga keabsahan data maka pada penelitian ini menggunakan triangulasi data. Menurut Bachri (2012) triangulasi metode adalah usaha mengecek keabsahan data atau mengecek keabsahan temuan penelitian. Triangulasi metode dapat dilakukan dengan lebih dari satu teknik pengumpulan data untuk mendapatkan data yang sama, serta pelaksanaannya juga dapat dengan cek dan recek.

\section{HASIL DAN PEMBAHASAN}

Pendidikan karakter merupakan topik yang sedang banyak dibincangkan saat ini karena banyaknya kasus penyimpangan yang diakibatkan oleh lemahnya karakter seseorang. Karakter adalah sifat, peilaku, budi pekerti yang baik yang dimiliki oleh manusia. Karakter tersebut dapat dipupuk dan dikembangkan semakin baik. Namun, juga dapat mengalami penurunan apabila terpengaruh oleh hal-hal yang bersifat negatif. Oleh karena itu, pendidikan karakter sangat penting dikembangkan disekolah. Pendidikan karakter menurut Yusuf (2017:12) adalah upaya yang terencana untuk menjadikan peserta didik mengenal, peduli dan menginternalisasi nilai-nilai sehingga peserta didik berlaku sebagai insan kamil. Hal ini senada dengan pendapat menurut Ratna Megawangi dalam Kesuma (2013:05) yang menyebutkan bahwa pendidikan karakter merupakan sebuah usaha untuk mendidik anak-anak agar dapat mengambil keputusan dengan bijak dan mempraktikannya dalam kehidupan sehari-hari sehingga mereka dapat memberikan kontribusi yang positif pada lingkungannya.

Berbagai kegiatan dan usaha untuk menamkan nilai-nilai karakter sudah banyak dilakukan. Salah satu inovasi penanaman nilai-nilai karakter adalah melalui kegiatan pembiasaan menyanyikan lagu anak-anak. Lagu anak-anak dijadikan alternatif sebagai sarana untuk menanmkan nilai-nilai karakter dikarenakan sifat dari lagu tersebut yang ringan dan mudah dipahami bagi kalangan anak-anak.

Lagu anak adalah lagu yang dirancang dan disesuaikan dengan karakteristik anak. Lagu anak memiliki sifat yang ceria dan bahasanya bersifat sederhana. Lagu anak dibuat untuk mengungkapkan kegembiraan, kasing sayang, dan memiliki nilai pendidikan yang sesuai dengan tingkat psikologis anak. Syair lagu anak biasanya bercerita tentang cinta kasih pada sesama, Tuhan, ayah-ibu, kakak-adik, keindahan alam, kebesaran Tuhan yng ditulis dengan bahasa sederhana sesuai dengan alam pikir anak-anak (Kusumawati, 2013 :05).

Nilai-nilai pendidikan karakter yang dapat dihayati dalam penelitian ini adalah religius, nasionalis, cerdas, tanggungjawab, disiplin, mandiri, jujur, hormat, santun, kasih sayang, peduli, toleransi, rendah hati, percaya diri, goong royong, dan kerja keras. Pendidikan karakter melalui pembiasaan menyanyikan lagu anak-anak sudah diterapkan sejak lama oleh guru-guru di SDN 1 Depokrejo karena dianggap sebagai media yang tepat untuk diterapkan kepada anak usia SD yang memiliki karakteristik 
ceria dan senang bernyanyi. Kegiatan menyanyikan lagu anak-anak dilakukan setiap hari sebagai pengantar sebelum memulai kegiatan pembelajaran untuk mengkondisikan dan membangkitkan semangat siswa dalam belajar. Kegiatan bernyayi juga dilakukan disela-sela kegiatan pembelajaran terutama pada kelas yang sudah menggunakan kurikulum 2013 dimana lagu anak digunakan sebagai pengantar untuk mengaitkan dengan mata pelajaran lain, serta untuk menyegarkan pikiran siswa.

Kegiatan menyanyikan lagu anak-anak pada siswa kelas rendah di SDN 1 Depokrejo dilakukan dengan cara langsung maupun dengan menggunakan media audio visual berupa video. Setelah bernyanyi guru mengulas kata kunci dari setiap lirik lagu yang dinyanyikan. Hal ini dilakukan untuk menyampaikan amanat yang tekandung didalam lagu anak sebagai poin penting pendidikan karakter yang perluditanamkan dalam jiwa peserta didik. Cara ini dilakukan karena mengingat bahwa siswa kelas rendah masih kesulitan untuk menangkap dan memahami nilai pendidikan yang terkandung dari lagu jika hanya dinyanyikan saja.

Kegiatan pembiasaan menyanyikan lagu anak-anak untuk menanmkan nilai-nilai karakter pada siswa kelas rendah di SDN 1 Depokrejo mendapatkan respon yang baik dari siswa maupun orangtua. Perkembangan keberhasilan penanaman nilai-nilai karakter melalui lagu anak-anak bagi siswa dapat dilihat dari kegiatan keseharian anak disekolah yang lebih tertib, sadar akan kebersihan, menghargai sesama teman, dan menghormati bapak dan ibu guru. Orang tua juga memberikan respon yang positif kepada sekolah karena dengan adanya pembiasaan lagu anak-anak di sekolah anak menjadi terbiasa bernyanyi lagui anak-anak bukan lagu orang dewasa.

Banyak sekali lagu yang diajarkan dan dibiasakan dinyanyikan di dalam kelas. Dalam hal ini penyampaiannya biasanya guru menuliskan terlebih dahulu menuliskan liriknya di papan tulis, kemudian menanyakan kepada siswa apaka sudah ada yang bisa menyanyikan lagu tersebut. Apabila belum ada yang bisa, maka guru mencontohkannya terlebih dahulu. Setelah dicontohkan barulah siswa dan guru menyanyikan lagunya secara bersama-sama. Untuk menanamkan sikap percaya diri guru menawarkan kepada siswa untuk menyanyikannya di depan kelas. Apabila terdapat siswa yang berani menyanyikan lagu di depan kelas maka siswa yang lain diarahkan untuk memberikan apresiasi dengan bertepuk tangan. Dengan bertepuk tangan secara tidak langsung guru mengajarkan kepada siswa untuk membiasakan diri menghargai orang lain.

Lagu anak-anak yanng dinyanyikan diharapkan dapat mengajarkan berbagai macam hal positif untuk memancing anak berperilaku sesuai dengan usia mereka. Beberapa lagu yang biasa dinyanyikan di kelas rendah SDN 1 Depokrejo contohnya adalah lagu "Bangun Tidur", "Kasih Ibu", "Satu-satu Aku Sayang Ibu", "Ruri Abangku", "Siapa Namamu", "Dua Mata Saya", "Pergi Belajar", "Naik ke Puncak Gunung", "Layang-Layang, "Sebelum Kita Makan”, "Padang Bulan”, "Buang Sampah”.

Contoh 1

\section{Buang Sampah}

Jangan membuang sampah dimana-mana

Jagalah kebersihan di lingkunganmu

Sampah di rumahmu

Sampah di halaman

Sapu dan bersihkan

Buang di tempatnya 
Sapu dan bersihkan

Buang di tempatnya

Dalam lagu buang sampah disini guru menjelaskan bahwa isi atau makna dari lagutersebut adalah kita harus membunag sampah pada tempatnya serta menjagakebersihan dimanapun kita berada.

Contoh 2

\section{Ruri Abangku}

Ruri adalah abangku

Rajin dan senang belajar

Dengan menyandang tas di bahu

Riang menuju sekolah

Berhitung, menulis, membaca

Tak lupa di ulang di rumah

Ingin akupun demikian

Serajin Ruri abangku

Dalam lagu Ruri Abangku disini guru menjelaskan bahwa isi atau makna yang terkandung dalam lagu tersebut adalah kita harus bersemangat, rajin dalam menuntut ilmu, serta selalu mengulas kembali pelajaran yang sudah dipelajari di sekolah di rumah.

Untuk mengevaluasi keberhasilan penanaman nilai-nilai karakter melalui lagu anak-anak, guru kelas rendah di SDN 1 Depokrejo mengamati perubahan sikap dan perilaku anak dalam kehidupan sehari-hari. khususnya pada saat di lingkungan sekolah dengan pengamatan secara langsung yang tidak disadari oleh anak. Dengan cara tersebut, guru dapat melihat tingkah laku anak yang sebenar-benarnya. Berdasarkan hasil wawancara dengan guru SDN 1 Depokrejo, dapat dicontohkan bahwa kegiatan penanaman nilai-nilai karakter melalui lagu anak-anak yang berjudul ("Membuang Sampah") dapat terlihat perubahan perilaku anak, yaitu saat pelaksanaan kegiatan piket kelas yang dimana siswa semula tidak sadar dan perduli terhadap kebersihan kelas berubah menjadi sadar dan perduli terhadap kebersihan di lingkungan kelasnya. Dengan memanfaatkan lagu anak-anak sebagai penanaman nilai-nilai karakter, anak diharapkan berkembang sesuai dengan tahapan usianya dan tidak mudah terpengaruh dengan hal-hal yang negatif. Kegiatan ini tentunya sangatlah efektif untuk menanamkan nilai-nilai karakter melalui lagu anak-anak. Sehingga nilainilai karakter baik dapat tertanam dengan baik pada diri anak.

\section{SIMPULAN}

Berdasarkan perumusan masalah penelitian serta pembahasan dapat disimpulkan bahwa menanamkan nilai-nilai karakter pada anak merupakan tanggungjawab kita semua. Pembiasaan menyanyikan lagu anak-anak untuk menanamkan nilai-nilai karakter pada siswa kelas rendah di SDN 1 Depokrejo disampaikan guru dengan cara melatih dan membiasakan siswa untuk bernyanyi serta menjelaskan makna dari lagu yang dinyanyikan. Kegiatan menyanyikan lagu anak- 
anak sudah diterapkan sejak lama di SDN 1 Depokrejo, karena dianggap efektif untuk menanamkan nilai-nilai karakter dan sesuai dengan karakteristik anak. Manfaat penanaman nilai karakter melalui lagu anak-anak dapat dilihat dari perubahan sikap yang lebih baik dari sebelumnya, misalnya lebih menghargai sesama teman, memaafkan, sopan santun, menjaga kebersihan, dan lain sebagainya.

\section{DAFTAR PUSTAKA}

Bachri, B.S.(2012). Meyakinkan Validitas Data melalui Triangulasi padaPenelitian Kualitatif. Diakses di http://yusuf.staff.ub.ac.id>files>2012/11 pada 5 Oktober 2018 Chowdury, M. 2016. Emphasizing Morals, Values, Ethics, And Character Education In Sceince Education And Sceince Teaching. Australia. The Malaysian Online Journal of Educational Sceince Volume 4 - Issue 2.

Gumilang GS. 2017. Internalization Of Philosophical Value "Tembang Macapat" In Guidace and Counseling. Jurnal Proseding SNBK. Vol 01 No 1, 62-77

Indrastoeti Jenny. 2016. Penanaman Nilai-Nilai Karakter Melalui Implementasi Pendidikan Karakter di Sekolah Dasar. Diakses dari http://jurnal.fkip.uns.ac.oid>article>viewfilepada 3 Oktober 2018

Nafis. 2013. Dikases dari eprints.walisongo.ac.id>083111071_Bab3 pada 4 Oktober 2018

Kesuma Dharma, Cepi Triatna, dan Johar Permana. 2013. Pendidikan Karakter. Bandung : PT Remaja Rosdakarya

Kusumawati, Heni. 2013. Pendidikan Karakter Melalui Lagu Anak-Anak. Diakses Dari http://staffnew.uny.ac.id/upload/132001801/penelitian/PENDIDIKAN+KARAKTER +MELALUI+LAGU+ANAK+FINAL.pdf pada 24 September2018

UU No 20 Tahun 2003 Tentang Sistem Pendidikan Nasional diakses dari kelembagaan.ristekdikti.go.id/wpcontent/uploads/2016/08/UU_no_20_th_ 3003.pdf pada 20 September 2018

Yusuf, Munawir. 2017. Pendidikan Karakter Menuju Generasi Emas 2045. Diakses dari jurnal. fkip.uns.ac.id/indekx.php/snip/article/download/11140/7930 pada 20 September 2018 